\title{
Influential Factors in Selecting an Overseas University for Bangladeshi Undergraduate Students
}

\author{
Rashedul Hasan \\ Senior Lecturer, American International University Bangladesh (AIUB)
}

\begin{abstract}
In Bangladesh, the number of students passing in Higher Secondary level is increasing every year. But the number of seats in public universities is not increase in proportion. So, the next choice is to get admission in private universities. But again, there are few private universities in Bangladesh which maintains the quality for higher education. As a result, many talented students look for a foreign university to get a higher degree. This study was conducted to understand the important factors that influence the selection an overseas university among Bangladeshi university students with a self administered questionnaire. A total of 100 questionnaires were analyzed using regression in SPSS to come up with a justified conclusion. The result from the analysis indicates that the regression model used in the study is statistically significant and the independent variables that were selected in this study had significant influence on the dependent variable. The primary aim of this research was to help private universities in Bangladesh to attract more talented students.
\end{abstract}

Keywords: $\quad G D P, C G P A, H E I, U G C$, Overseas, Undergraduate

\section{INTRODUCTION}

In 2012, 926814 students participated in H.S.C/ Alim Exam from different boards in Bangladesh and among them 51469 students achieved the highest grade of GPA 5 (Ministry of Education, 2012). Now these students will fight to get one of the limited seats of a public university according to their choice. Those who would not get this opportunity will look for an admission in a private university. But there are only 34 public and 54 private universities available in Bangladesh to satisfy the needs of a huge number of customers seeking for a higher education (UGC, 2012). As a result, many of those students are looking for a foreign university to complete their graduation. But selecting a university in a foreign country is a very huge step which has a direct impact in their future career and is influenced by but not limited to factors such as academic reputation and recognition, campus environment, reference group influence, program relevancy, informational information, financial cost and accessibility and location. Thus, this paper is aimed to understand the behavior of Bangladeshi students in selecting a university to conduct their graduation / post - graduation in Malaysia. The primary reason in selecting Malaysia for this study is because it is a perfect place for both Muslim and non-Muslim students with an excellent public transportation system and lower of cost of living as compared to the European countries which is very important for non only a Bangladesh but also for any international students to settle in any foreign country. At the end of this paper, I have tried to answer the question: what are the factors that influence Bangladeshi students' decision in selecting a university for higher education.

\section{Review of Literature}

Education and education marketing is a service industry and this presents a particular set of challenges for practitioners (Ross, Heaney and Cooper, 2007) and in the service industry the main focus is the studentscum-customers. In the US, education is the second largest export market after agriculture and the second largest domestic industry after health care (Abeless 2001). Currently, the US is the leader in the market, for international education, followed by the UK and Australia (Binsardi and Ekwulugo, 2003). In terms of investment, countries such as Australia, Canada, the US and Korea invests respectively 1.1, 1.5, 2.5 and 2.7 per cent of their GDP on higher education (Cornuel, 2007). As a result, most of the studies related to student behavior in selecting a university were conducted focusing on those countries. According to Mazzarol and Soutar (2002) there are many factors influencing students to choose international education, such as lack of access to higher education especially in Asia and Africa, a commonality of languages and availability of technology-based programs. According to Baharun, Kamaruddin \& Padlee (2010), very little is written about Malaysian education in the international arena and by conducting a research on Malaysia they have found that the most related items to services are quality education, cost, and facilities provided by the HEIs are the key aspects that determine the decision-making process by the international students and these factors should be addressed by the HEIs. Another relatively similar study conducted by Awang, Baharun \& Padlee (2010), has found that quality of education is likely to remain the most important factor influencing study destination choice among international students. Fernandez (2010) conducted a study on factors influencing the decision of students to study at a particular university in Malaysia - Universiti Sains Malaysia. The results of the study 
indicated that the main reasons that students pursue higher education were to improve their job prospects, to gain knowledge and experience. In another study, Wagner \& Fard (2009) identified the main factors that significantly influence students' intention to study at a higher educational institution in Malaysia. Sia's (2010) study explored the institution factors that influence students' college choice decision in Malaysia. Paramewaran and Glowacka (1995) in their study of university image found that HEIs need to maintain or develop a distinct image in order to create a competitive advantage in an increasingly competitive market. In a number of countries, governments have continuously stressed on the economic benefits resulting from higher education (Yorke,1999).

\section{Research Objectives}

The primary goal of the study is to find out the major influential factor for Bangladeshi student's decision in selecting a university for higher education in Malaysia. In addition, this study would like to:

1. Determine the role of different factors in the final decision making.

2. Suggest some recommendations for Foreign Universities to attract local student.

3. Suggest some recommendations for local universities to retain local students.

4. Propose some area for future research on this related topic.

\section{Sample:}

\section{Methodology}

According to Zikmund (2012), the goal of sampling is to be able to make inferences about the population parameter from knowledge of the relevant statistics to draw conclusions about the entire body of unites. Simple random sampling is used to conduct this research. The sample size used to conduct this research is 100 because to keep a sampling error of +/- 10 from a population of more than 100,000 , it better to use this sample size. (Yamane, Taro. 1967) All of the respondents are students of American International University perusing their undergraduate degree from Business Administration department.

\section{Research Design \& Tools Used:}

This descriptive research was conducted based on quantitative method for data collection where the questionnaire was designed after analyzing the study conducted by Chai (2006). A total of 7 independent variables were considered in the questionnaire and the responses were analyzed in SPSS (Statistical Package for Social Sciences). Correlation and regression tests were run using SPSS to reach a satisfactory conclusion.

\section{Conceptual Framework}

The conceptual framework of the descriptive research is designed by clearly defying the dependent and independent variables so that readers of this research paper have a very clear understanding.

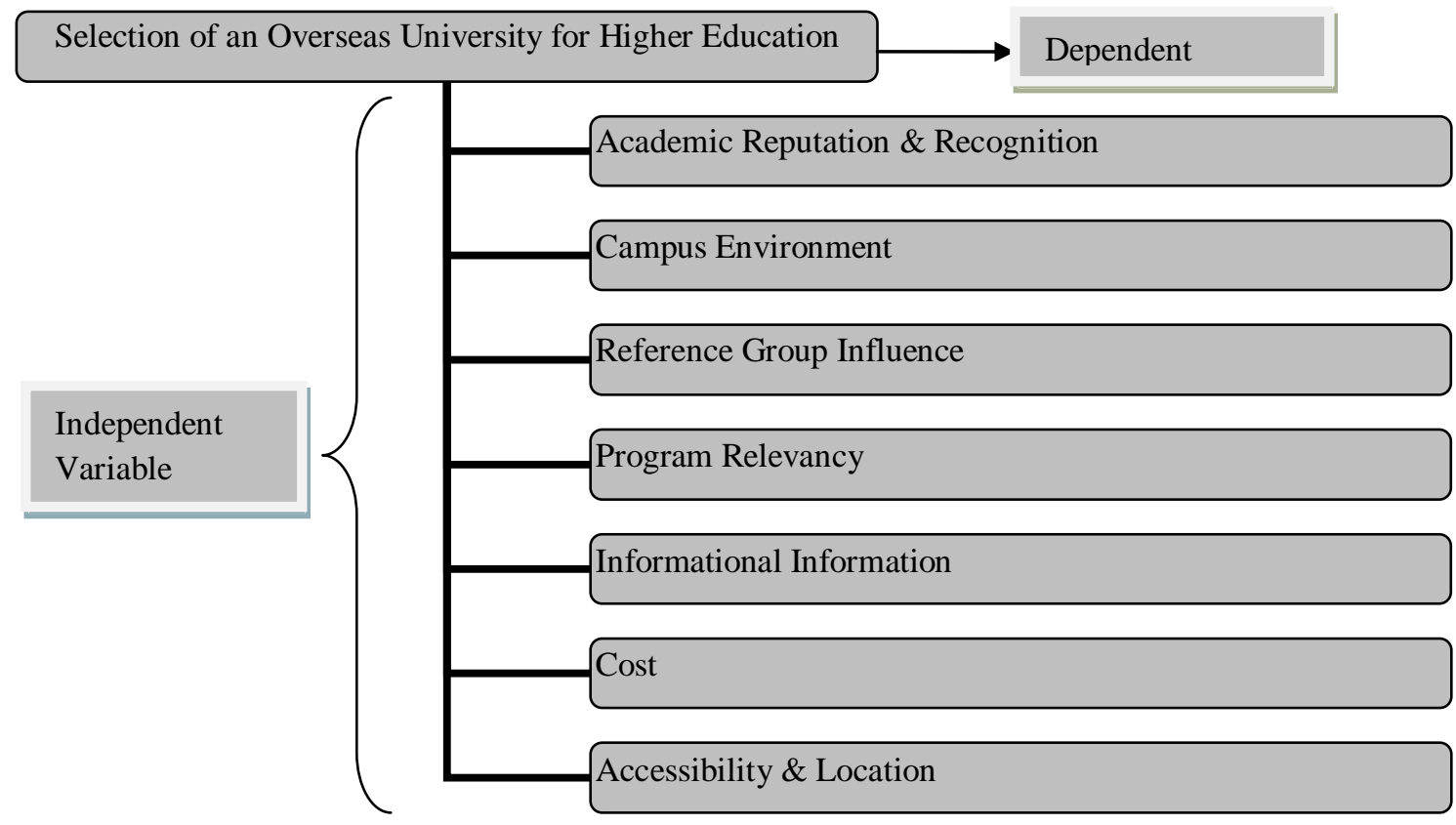

Figure - 1: Conceptual Framework of the Research 


\section{Hypothesis}

H1: There is a significant positive influence of Academic Reputation and recognition on the section of a university for higher education.

H2: There is a significant positive influence of Campus Environment on the section of a university for higher education.

H3: There is a significant positive influence of Reference Group influence on the section of a university for higher education.

H4: There is a significant positive influence of Program Relevance on the section of a university for higher education.

H5: There is a significant positive influence of Informational Information on the section of a university for higher education.

H6: There is a significant positive influence of Cost on the section of a university for higher education.

H7: There is a significant positive influence of Accessibility and location on the section of a university for higher education.

\section{Statistical Analysis}

\subsection{Descriptive Statistical Analysis:}

As mentioned before, the sample size of the research is 100 which are dominated by male students with $63 \%$. Also from the table -2 , we can see that the majority of the students are in 7 th semester. It means that they have already spent almost two years in the university and are quite capable of deciding where they would like to go for their higher education in future. Table -3 gives shows that $48 \%$ of the students' parents are businessman. It gives us some indication about the ability of the students to peruse a post graduate degree in any country outside Bangladesh.

\begin{tabular}{|l|c|c|c|}
\hline \multicolumn{4}{|c|}{ GENDER } \\
\hline & Frequency & Percent & $\begin{array}{c}\text { Cumulative } \\
\text { Percent }\end{array}$ \\
\hline Male & 63 & 63.0 & 63.0 \\
\hline Female & 37 & 37.0 & 100.0 \\
\hline Total & 100 & 100.0 & \\
\hline
\end{tabular}

Table - 1

\begin{tabular}{|l|c|c|c|}
\hline \multicolumn{4}{|c|}{ PARENT'S OCCUPATION } \\
\hline & Frequency & Percent & $\begin{array}{c}\text { Cumulative } \\
\text { Percent }\end{array}$ \\
\hline Businessman & 48 & 48.0 & 48.0 \\
\hline Job Holder(Govt.) & 27 & 27.0 & 75.0 \\
\hline Job Holder(Private) & 25 & 25.0 & 100.0 \\
\hline
\end{tabular}

Table - 2

\begin{tabular}{|c|c|c|c|}
\hline \multicolumn{3}{|c|}{ SEMESTER } \\
\hline & Frequency & Percent & $\begin{array}{c}\text { Cumulative } \\
\text { Percent }\end{array}$ \\
\hline $\mathbf{2 . 0 0}$ & 1 & 1.0 & 1.0 \\
\hline $\mathbf{4 . 0 0}$ & 2 & 2.0 & 3.0 \\
\hline $\mathbf{5 . 0 0}$ & 3 & 3.0 & 6.0 \\
\hline $\mathbf{6 . 0 0}$ & 20 & 20.0 & 26.0 \\
\hline $\mathbf{7 . 0 0}$ & 41 & 41.0 & 67.0 \\
\hline $\mathbf{8 . 0 0}$ & 15 & 15.0 & 82.0 \\
\hline $\mathbf{9 . 0 0}$ & 11 & 11.0 & 93.0 \\
\hline $\mathbf{1 0 . 0 0}$ & 2 & 2.0 & 95.0 \\
\hline $\mathbf{1 1 . 0 0}$ & 4 & 4.0 & 99.0 \\
\hline $\mathbf{1 2 . 0 0}$ & 1 & 1.0 & 100.0 \\
\hline Total & 100 & 100.0 & \\
\hline
\end{tabular}

Table - 3

\section{Regression Analysis}

With an aim to understand the influence of independent variables (accessibility \& location, cost, reference group influence, academic reputation \& recognition, program relevancy, informational information, campus environment) on the dependent variable (selection of a university) a multiple linear regression analysis was conducted. The ANOVA table presented below indicates a significance value of 0.000 . So the model is accepted as $\mathrm{p}$ value is less than 0.055 . 


\begin{tabular}{|l|l|l|l|r|c|c|}
\hline \multicolumn{7}{|c|}{ ANOVA } \\
\hline \multicolumn{2}{|l|}{ Model } & Sum of Squares & df & Mean Square & F & Sig. \\
\hline \multirow{3}{*}{1} & Regression & 15.015 & 7 & 2.145 & .000 & $.000 \mathrm{a}$ \\
\cline { 2 - 7 } & Residual & .000 & 92 & .000 & & \\
\cline { 2 - 7 } & Total & 15.015 & 99 & & & \\
\hline $\begin{array}{l}\text { a. Predictors: (Constant), Accessibility \& Location, Cost, Reference Group } \\
\text { Influence, Academic Reputation \& Recognition, Program Relevancy, } \\
\text { Informational Information, Campus Environment }\end{array}$ \\
\hline \multicolumn{2}{|l|}{ b. Dependent Variable: UNIVERSITY SELECTION } \\
\hline
\end{tabular}

Table - 4

The model summary table presented below represents how well the regression model fit the observed data. The value of R Square is 1.000 which clearly indicates that approximately $100 \%$ of the variance in the dependent variable can be accounted for by independent variables.

\begin{tabular}{|c|c|c|c|c|c|c|c|}
\hline \multicolumn{8}{|c|}{ MODEL SUMMARY } \\
\hline \multirow[b]{2}{*}{ Model } & \multirow[b]{2}{*}{$\mathbf{R}$} & \multirow[b]{2}{*}{$\begin{array}{l}\mathbf{R} \\
\text { Square }\end{array}$} & \multirow[b]{2}{*}{$\begin{array}{l}\text { Adjusted } \\
\text { R Square }\end{array}$} & \multirow{2}{*}{$\begin{array}{l}\text { Std. } \\
\text { Error of } \\
\text { the } \\
\text { Estimate }\end{array}$} & \multicolumn{3}{|c|}{ Change Statistics } \\
\hline & & & & & df1 & df2 & $\begin{array}{l}\text { Sig. F } \\
\text { Change }\end{array}$ \\
\hline 1 & $1.000 \mathrm{a}$ & 1.000 & 1.000 & .00000 & 7 & 92 & .000 \\
\hline
\end{tabular}

Table - 5

The Coefficient table provides an idea about the statistical significance of the independent variables. As the significance value for each independent variable is $0.000(p<0.055)$, so the simplest way to interpret is all independent variable used in the model to conduct the regression analysis is statistically significant for this study.

\begin{tabular}{|l|l|l|l|l|}
\hline \multicolumn{5}{|c|}{ COEFFICIENTS } \\
\hline \multirow{2}{*}{ Model } & & $\begin{array}{l}\text { Unstandardized } \\
\text { Coefficients }\end{array}$ & $\begin{array}{l}\text { Standardized } \\
\text { Coefficients }\end{array}$ & Sig. \\
\hline & & B & Beta & \\
\hline 1 & (Constant) & .000 & & 1.000 \\
\hline & Campus Environment & .125 & .173 & .000 \\
\hline & $\begin{array}{l}\text { Academic Reputation \& } \\
\text { Recognition }\end{array}$ & .188 & .233 & .000 \\
\hline & Program Relevancy & .156 & .215 & .000 \\
\hline & Reference Group Influence & .156 & .333 & .000 \\
\hline & Informational Information & .125 & .240 & .000 \\
\hline & Cost & .125 & .201 & .000 \\
\hline & Accessibility \& Location & .094 & .192 & .000 \\
\hline
\end{tabular}

Table - 6

\section{Findings}

After analyzing results provided by the regression analysis, it is confirmed that all of the assumed independent variables have some influence on the dependent variable i.e selecting an overseas university. Now we have to take a closer look to determine the impact of each and every independent variable (whether positive and negative) on the dependent variable and this in turn will answer whether null or alternate hypothesis is 
accepted. Hypothesis 1 assumes that there is a significant positive influence of Academic Reputation and Recognition on the section of a university for higher education. From the coefficient table we can find that, the beta value of Academic Reputation and Recognition is 0.233. So, Hypothesis 1 is accepted. Hypothesis 2 assumes that there is a significant positive influence of Campus Environment on the section of a university for higher education. From the coefficient table we can find that, the beta value of Campus Environment is 0.173. So, Hypothesis 2 is accepted. Hypothesis 3 assumes that there is a significant positive influence of Reference Group influence on the section of a university for higher education. From the coefficient table we can find that, the beta value of Reference Group influence is 0.333 . So, Hypothesis 3 is accepted. Hypothesis 4 assumes that there is a significant positive influence of Program Relevance on the section of a university for higher education. From the coefficient table we can find that, the beta value of Program Relevance is 0.215 . So, Hypothesis 4 is accepted. Hypothesis 5 assumes that there is a significant positive influence of Informational Information on the section of a university for higher education. From the coefficient table we can find that, the beta value of Informational Information is 0.240 . So, Hypothesis 5 is accepted. Hypothesis 6 assumes that there is a significant positive influence of Cost on the section of a university for higher education. From the coefficient table we can find that, the beta value of Informational Information is 0.201. So, Hypothesis 6 is accepted. Hypothesis 7 assumes that there is a significant positive influence of Accessibility and Location on the section of a university for higher education. From the coefficient table we can find that, the beta value of Accessibility and location is 0.192 . So, Hypothesis 7 is also accepted. From the above analysis it also evident that among all the independent variable, reference group influence have the most significant influence on a Bangladeshi student while selecting an overseas university for higher education.

\section{Conclusion}

This research was conducted to have a better and more meaningful understanding about the important factors that influence the decision of a student searching for a foreign university for higher education with intent to help both local and foreign universities to attract more qualified students. I hope in future more research will be conducted on this issue with different sample size, reference group or using other research tool by me or someone else in Bangladesh. As from my research, I have found that reference group influence, informational information and academic reputation and recognition are the top most influential factors in selecting an overseas university, so I would like to advice both all higher education institutions specially private universities in Bangladesh to tailor their advertisement and curriculum in such a way which will enable them to attract more undergraduate students in different disciplines.

[1] Abeless, T. P. (2001). Rethinking the university. The Journal of Future Studies, Strategic Thinking andPolicy, 3(6), 563-568

[2] Baharun, A., Awang, Z., \& Padlee, S. F. (2010). International students choice criteria for selection of higher learning in malaysian private universities. (Vol. 5(12), pp. 4704-4714). African Journal of Business Management Retrieved from http://www.academicjournals.org/AJBM.

[3] Binsardi, A., \& Ekwulugo, F. (2003). International marketing of British education: Research on the students' perception and the UK market penetration. Marketing Intelligence \& Planning, 21(5), 318-327.

[4] Chia, Allan (2011). A Study of the Factors Influencing Students' Selection of a Private Educational Institution in Singapore and the Marketing Implications for the Institution (June 22, 2011). SIBR. Available at SSRN: http://ssrn.com/abstract=1869422 or http://dx.doi.org/10.2139/ssrn.1869422

[5] Cornuel, E. (2007). Challenges facing business schools in the future. Journal of Management Development, 26(1), 87-92.

[6] Fernandez, Jacqueline L. (2010). "An exploratory study of factors influencing the decision of students to study at University Sains Malaysia”. Kajian Malaysia, Vol. 28, No. 2, 2010.

[7] Mazzarol, T., \& Soutar, G. N. (2002). Push-pull factors influencing international student destination choice. International Journal of Educational Management, 16(2), 82-90.

[8] Paramewaran R, Glowacka AE (1995). University image: an information processing perspective. J. Mark. High. Educ., 6(2): 4156.

[9] Ross, M., Heaney, J., \& Cooper, L. (2007). Institutional and managerial factors affecting international student recruitment management. International Journal of Educational Management, 21(7), 593-605.

[10] Sia, Joseph K.M. (2010), “Institutional Factors Influencing Students' College Choice Decision in Malaysia: A Conceptual Framework", International Journal of Business and Social Science, Vol. 1 No.

[11] Yamane, Taro. 1967. Statistics: An Introductory Analysis, 2nd Ed. New York: Harper and Row.

[12] Yorke M (1999). Assuring quality and standards in globalised higher education. Qual. Assoc. Educ., 7(1): 14-24.

[13] Zikmund, W. G., Babin, B. J., Carr, J. C., \& Griffin, M. (2012). Business research methods. (9 ed.). Mason: CANGAGE LEARNING. 